\title{
Pneumococcal meningitis in Cantabria (Spain) in the pneumococcal conjugate vaccine era (2001-2015)
}

\author{
Esther González-Escartín, B.S. ${ }^{a}$, Itziar Angulo López, B.S. ${ }^{b}$, Elsa Ots Ruiz, B.S.c, \\ Luis Martínez-Martínez, M.D. ${ }^{b, d}$ and María J. Cabero Pérez, M.D. ${ }^{a, e}$
}

\begin{abstract}
Objective. To analyze the characteristics of pneumococcal meningitis in children $\leq 14$ years old following the market introduction of pneumococcal conjugate vaccines in our community.

Methods. Retrospective study of pneumococcal meningitis cases with a two-period analysis: pre-13-valent pneumococcal conjugate vaccine (PCV13) (2001-2010) and post-PCV13 (2010-2015). Patient demographic and clinical data, and microbiological data were collected.

Results. Eighteen cases were diagnosed. The mean incidence in the pre-PCV13 period was 2.3/100 000, which reduced to $0.5 / 100000$ after the PCV13 introduction. The most commonly identified serotypes were $6 \mathrm{~A}$ and $10 \mathrm{~A}$ (pre-PCV13); $6 \mathrm{~B}$ and 15B (post-PCV13, only 2 cases). Out of 18 patients, 13 were admitted to the intensive care unit. All cases were treated with cefotaxime, and 14/18 received dexamethasone. Six patients survived with sequelae, and 1 died.

Conclusion. A major reduction has been observed in the incidence of pneumococcal meningitis since the introduction of the PCV13 to the market, so an even greater reduction is expected following its systematic introduction.

Keywords:meningitis, Streptococcus pneumoniae, immunization, pediatrics.
\end{abstract}

http:/ /dx.doi.org/10.5546/aap.2017.eng.160

\footnotetext{
To cite: González-Escartín E, Angulo López I, Ots Ruiz E, et al. Pneumococcal meningitis in Cantabria (Spain) in the pneumococcal conjugate vaccine era (2001-2015). Arch Argent Pediatr 2017;115(2): 160-164.
}

a. Department of Pediatrics, Hospital Universitario Marqués de Valdecilla, Santander (Cantabria), Spain.

b. Department of Microbiology, Hospital Universitario Marqués de Valdecilla, Santander (Cantabria), Spain.

c. Department of Intensive Care Medicine. Pediatric Intensive Care Unit, Hospital Universitario Marqués de Valdecilla, Santander (Cantabria), Spain.

d. Department of Molecular Biology, School of Medicine, Universidad de Cantabria, Santander (Cantabria), Spain

e. Department of Medical and Surgical Sciences, School of Medicine, Universidad de Cantabria, Santander (Cantabria), Spain.

E-mail address:

Itziar Angulo López, B.S.: itzupitzu@gmail.com

Funding: None.

Conflict of interest: None.

Received: 6-15-2016

Accepted: 9-7-2016

\section{INTRODUCTION}

Streptococcus pneumoniae is one of the main causative agents of bacterial meningitis among children in Spain due to the lower number of Haemophilus influenzae type b and Neisseria meningitidis serogroup $\mathrm{C}$ infections following the systematic immunization against such microorganisms. ${ }^{1}$ Pneumococcus may cause two different forms of disease: non-invasive and invasive pneumococcal disease (IPD) (meningitis, bacteremia, sepsis, bacteremic pneumonia, etc.). ${ }^{2}$

The introduction of pneumococcal conjugate vaccines (PCV) has modified the epidemiology of pneumococcal meningitis (PM). Since the approval of the 7-valent pneumococcal conjugate vaccine (PCV7) in Spain in January 2001, serotypes have been displaced and the prevalence of those serotypes not included in the vaccine, e.g. 1, 19A and 6, increased. ${ }^{3}$ However, since the introduction of the PCV13 to the market in June 2010, the overall incidence of PM and the abovementioned serotypes has declined. ${ }^{4}$

The Hospital Universitario Marqués de Valdecilla is a tertiary care facility and referral center for pediatric health care in Cantabria, an autonomous community in northern Spain with 582571 inhabitants. ${ }^{5}$ In this community, the pneumococcal vaccine was optional until June 2015, when the PCV13 was introduced into the pediatric immunization schedule. Immunization coverage in the period after its introduction reached $91 \%$ of all children who could potentially receive the vaccine. There are no reliable records on immunization coverage for the period before the introduction because such coverage is estimated based on vaccine doses administered at the official immunization centers and do not include those given in a pharmacy or in the private sector.

In Cantabria, where the current pediatric population ( $\leq 14$ years old) is approximately 80000 inhabitants, ${ }^{5}$ the mean incidence of PM in children $<5$ years old was 2.3/100 000 in the 1977-1990 period and 5.2/100 000 in the 1995-2001 period. ${ }^{6}$ However, since the market introduction of the PCVs, no study has been conducted to 
establish the incidence of PM in the pediatric population of our community. For this reason, the objective of this study was to describe the epidemiological, clinical, and microbiological characteristics of pediatric patients diagnosed with PM in the period following PCV market introduction.

\section{POPULATION AND METHODS}

Retrospective and descriptive study of $S$. pneumoniae bacterial meningitis cases in Cantabria between January 2001 and December 2015. Patients $\leq 14$ years old who met the clinical criteria of meningitis with isolation of S. pneumoniae in cerebrospinal fluid (CSF) and/or blood were included.

The study was approved by the hospital's Ethics Committee prior to its conduct. Cases were searched for by selecting the PM code included in the main diagnosis of the Specialized Care Activity Log - Basic Minimum Dataset of Hospital Discharge. In addition, pneumococcal strains that had been isolated and sent to the National Microbiology Center (Instituto de Salud Carlos III, Majadahonda) were retrieved from the records of the Department of Microbiology.

Demographic, clinical, and analytical data were collected from medical records. S. pneumoniae strains were serotyped at the National Microbiology Center by means of the Quellung reaction and/or the dot-blot technique. In addition, the agar dilution method was used to establish antibiotic sensitivity to penicillin, cefotaxime, and vancomycin. The clinical category was construed based on the cut-off values for meningitis established in the EUCAST 2016 document. $^{7}$

Data were compared between two periods: pre-PCV13 (2001-2010) and post-PCV13 (20112015); PM incidence was estimated based on demographic data provided for Cantabria by the National Statistics Institute. ${ }^{5}$ The impact of immunization on the serotypes that caused meningitis in the studied periods was also assessed.

The statistical analysis was performed with the SPSS 18.0 software.

\section{RESULTS}

Eighteen cases of PM were diagnosed between 2001 and 2015. Demographic and clinical data of studied patients are described in Table 1, and lab test outcome measures at the time of diagnosis are shown in Table 2.
The annual and mean incidence values in the studied periods are reflected in Figure 1. The causative serotype distribution is shown in Figure 2. Eight different serotypes were identified in the PCV7 period, and only 2 of these were included in this vaccine (4 and 19F). In the postPCV13 period, 2 serotypes were isolated. One of those -6B- was included in the PCV13. Out of all identified serotypes, 4 were not included in any of the PCVs.

Only 3/18 patients had received the PCV. In the pre-PCV13 era, one patient received one dose of the PCV7 but the causative strain was nontypeable; another patient received 4 doses of the PCV7, and the serotype isolated in this case was 7F (not included in the vaccine). In the post-PCV13 era, 2 PM cases were identified. One of these was a patient who received the PCV13; in this case, serotype 15B was identified, which is not included in the vaccine. The second patient had not been immunized, and the isolated serotype was $6 \mathrm{~B}$, included in both vaccines.

S. pneumoniae was isolated in the CSF in $16 / 18$ cases; in the blood in 13/18; and in both in 11/18. The antibiotic sensitivity analysis indicated that 7 strains were resistant to penicillin, 3 showed intermediate sensitivity to cefotaxime, and all were sensitive to vancomycin. No differences were observed in terms of antibiotic sensitivity between both periods or in the type of serotype.

\section{DISCUSSION}

In Cantabria, following the introduction of the PCVs, an overall reduction has been recorded in the incidence of PM in children, especially since the introduction of the PCV13 to the market.

The introduction of the PCV7 to the market not only drastically reduced IPD caused by vaccine serotypes, it has also been accompanied by an increase in the invasive forms caused by serotypes not included in the PCV7, such as 1 , 19A, 7F, 3, and 6A. ${ }^{8}$

In our case, the incidence of meningitis peaked in the 2008-2009 period due to the nonvaccine serotypes $1,7 \mathrm{~F}$, and $10 \mathrm{~A}$. In most series, the most striking change was the increase in serotype 19A, which is associated with almost all high-level resistance to cefotaxime in the meningitis causative strains. ${ }^{2}$ In Madrid, it caused $20-25 \%$ of all PM cases. ${ }^{9}$ However, in our series, we did not identify any case caused by this serotype. PM is caused by a wide range of serotypes; and many of these are not included in any of the new PCVs. ${ }^{2}$ 
162 / Arch Argent Pediatr 2017;115(2):155-168 / Brief reports

TABLE 1. Demographic and clinical data of patients with S. pneumoniae meningitis $(n=18)$

\begin{tabular}{|c|c|c|}
\hline & & $\mathbf{N}$ \\
\hline$\underline{\text { Sex }}$ & Female: & 9 \\
\hline Age & $\begin{array}{l}\text { Younger than } 6 \text { months old: } \\
6-12 \text { months old: } \\
\text { 1-2 years old: } \\
\text { Older than } 2 \text { years old: }\end{array}$ & $\begin{array}{l}7 \\
4 \\
3 \\
4 \\
\end{array}$ \\
\hline Background disease n: 6 & $\begin{array}{l}\text { Preterm newborn infants: } \\
\text { Neoplasm: } \\
\text { ENT/respiratory pathology: }\end{array}$ & $\begin{array}{l}3 \\
1 \\
2 \\
\end{array}$ \\
\hline Underlying disease $\mathrm{n}: 11$ & $\begin{array}{l}\text { Upper respiratory tract infection: } \\
\text { Bronchiolitis: } \\
\text { Ventriculoperitoneal shunt valve: }\end{array}$ & $\begin{array}{l}8 \\
2 \\
1 \\
\end{array}$ \\
\hline Length of stay (mean and range) & & 16.4 days (10-33 days) \\
\hline Admission to the ICU & & 13 \\
\hline $\begin{array}{l}\text { Orotracheal intubation and } \\
\text { mechanical ventilation }\end{array}$ & & 6 \\
\hline Inotropic support & & 1 \\
\hline \multirow[t]{3}{*}{ IV antibiotic therapy } & $\begin{array}{l}\text { Cefotaxime: } \\
\text { Mean duration: } \\
\text { Dose: }\end{array}$ & $\begin{array}{l}18 \\
14 \text { days } \\
200 \mathrm{mg} / \mathrm{kg} / \text { day every } 8 \mathrm{~h} \\
\end{array}$ \\
\hline & $\begin{array}{l}\text { Vancomycin: } \\
\text { Mean duration: } \\
\text { Dose: }\end{array}$ & $\begin{array}{l}15 \\
4 \text { days }^{\mathrm{a}} \\
60 \mathrm{mg} / \mathrm{kg} / \text { day every } 6 \mathrm{~h}\end{array}$ \\
\hline & $\begin{array}{l}\text { Ampicillin: } \\
\text { Dose: } \\
\text { (Children younger than } 1 \text { year old) }\end{array}$ & $\begin{array}{l}5 \\
200 \mathrm{mg} / \mathrm{kg} / \text { day every } 6 \mathrm{~h}\end{array}$ \\
\hline Corticotherapy & $\begin{array}{l}\text { Dexamethasone: } \\
\text { Mean duration: }\end{array}$ & $\begin{array}{l}14 \\
2.8 \text { days }\end{array}$ \\
\hline Long-term sequelae $\mathrm{n}: 6^{\mathrm{b}}$ & $\begin{array}{l}\text { Motor: } \\
\text { Auditory: } \\
\text { Both: }\end{array}$ & $\begin{array}{l}3 \\
2 \\
1 \\
\end{array}$ \\
\hline Mortality & & $1^{\mathrm{c}}$ \\
\hline
\end{tabular}

UICU: intensive care unit.

${ }^{a}$ Empiric antibiotic therapy with vancomycin was started, and was then discontinued after obtaining antibiogram results.

${ }^{\mathrm{b}}$ Causative serotypes were 6A (3 cases), 4 (1), 6B (1), and 19F (1), all included in the PCV13. The serotypes included in the PCV13 caused a higher number of neurological sequelae $(\mathrm{p}=0.01)$ than those not included, which resulted in no type of sequelae.

c This was a 9-month-old patient without predisposing factors and affected by serotype 15C, which is not included in the PCV13, in the setting of severe sepsis and diffuse cerebral ischemia.

TABLE 2. Lab test values of patients $(n=18)$ with S. pneumoniae meningitis

\begin{tabular}{|c|c|c|c|}
\hline & \multicolumn{2}{|c|}{ Range } & \multirow[b]{2}{*}{ Average value $\pm \mathrm{SD}^{*}$} \\
\hline & Minimum value & Maximum value & \\
\hline $\mathrm{WBC} / \mathrm{mm}^{3}$ & 2500 & 45100 & $17439 \pm 12497$ \\
\hline Neutrophils (\%) & 9 & 84 & $63.5 \pm 20.1$ \\
\hline Band cells (\%) & 0 & 40 & $11.5 \pm 10.7$ \\
\hline $\mathrm{CRP}^{\mathrm{a}}(\mathrm{mg} / \mathrm{dl})$ & 4.5 & 51.6 & $23.6 \pm 11.4$ \\
\hline Procalcitonin ${ }^{\mathrm{b}}$ (ng/dl) & $<0.5$ & 96.7 & $41.4 \pm 29.8$ \\
\hline $\mathrm{CSF}_{\text {protein levelc }}(\mathrm{mg} / \mathrm{dl})$ & 63 & 407 & $177.6 \pm 88.1$ \\
\hline CSF glucose level (mg/dl)-blood glucose level (mg/dL)ratio & 0 & 0.47 & $0.14 \pm 0.16$ \\
\hline $\mathrm{WBC}$ in $\mathrm{CSF}^{\mathrm{c}} / \mathrm{mm}^{3}$ & 0 & 3180 & $1000 \pm 1108$ \\
\hline Neutrophils in $\mathrm{CSF}^{\mathrm{c}}(\%)$ & 0 & 99 & $81.8 \pm 23.3$ \\
\hline
\end{tabular}

* SD = standard deviation.

CSF: cerebrospinal fluid.

${ }^{a}$ C-reactive protein.

${ }^{\mathrm{b}}$ Established only in 8 patients.

${ }^{\mathrm{c}} \mathrm{CSF}$ obtained from 16 patients. It was not possible to perform lumbar puncture in 2 patients due to their poor clinical condition at the time of diagnosis. 
FIGURE 1. Annual incidence rate (no. of cases/100 000 inhabitants/year) for pneumococcal meningitis in Cantabria between January 2001 and December 2015

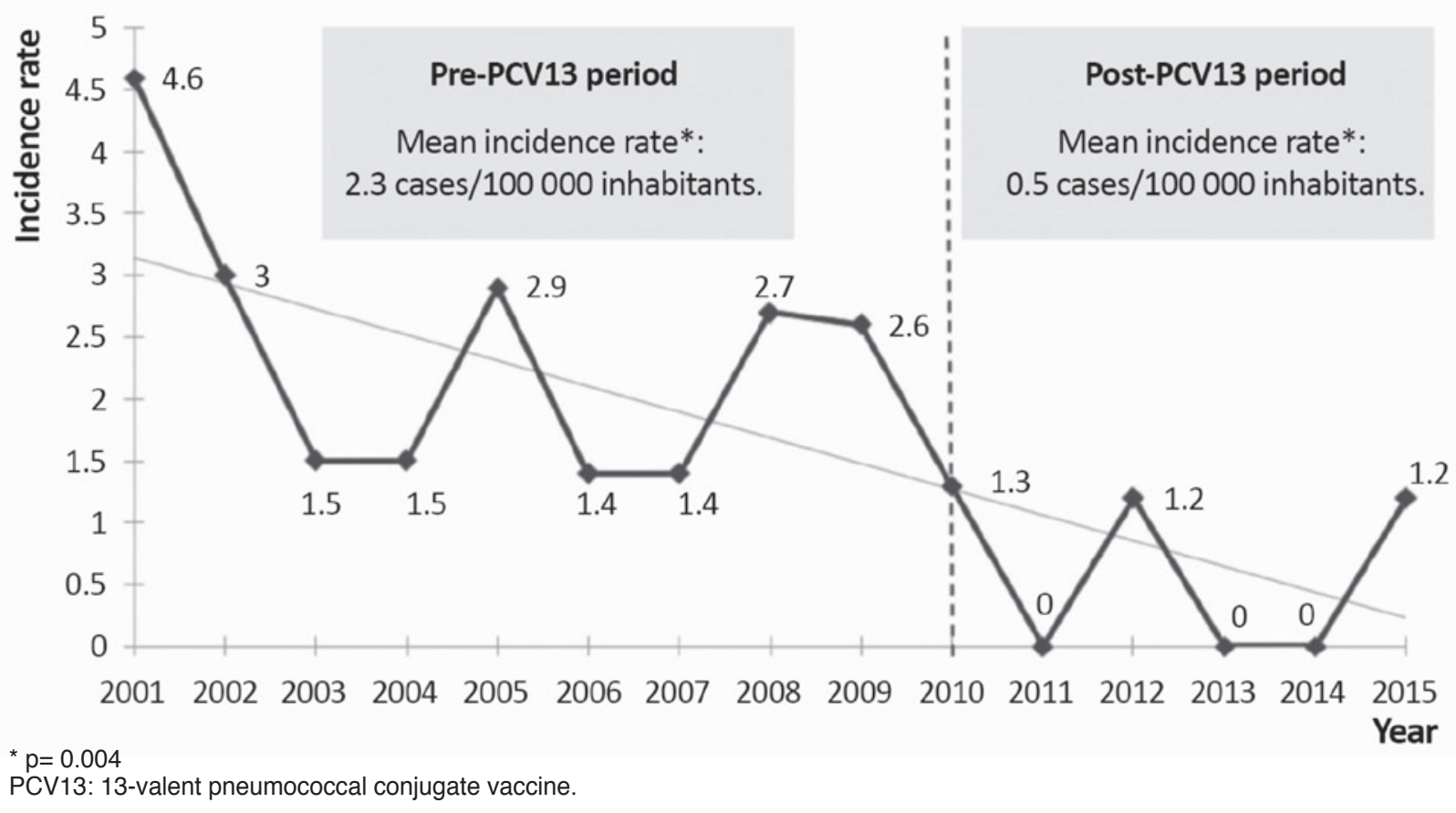

FIGURE 2. Serotype distribution in the pre-and post-13-valent pneumococcal conjugate vaccine periods

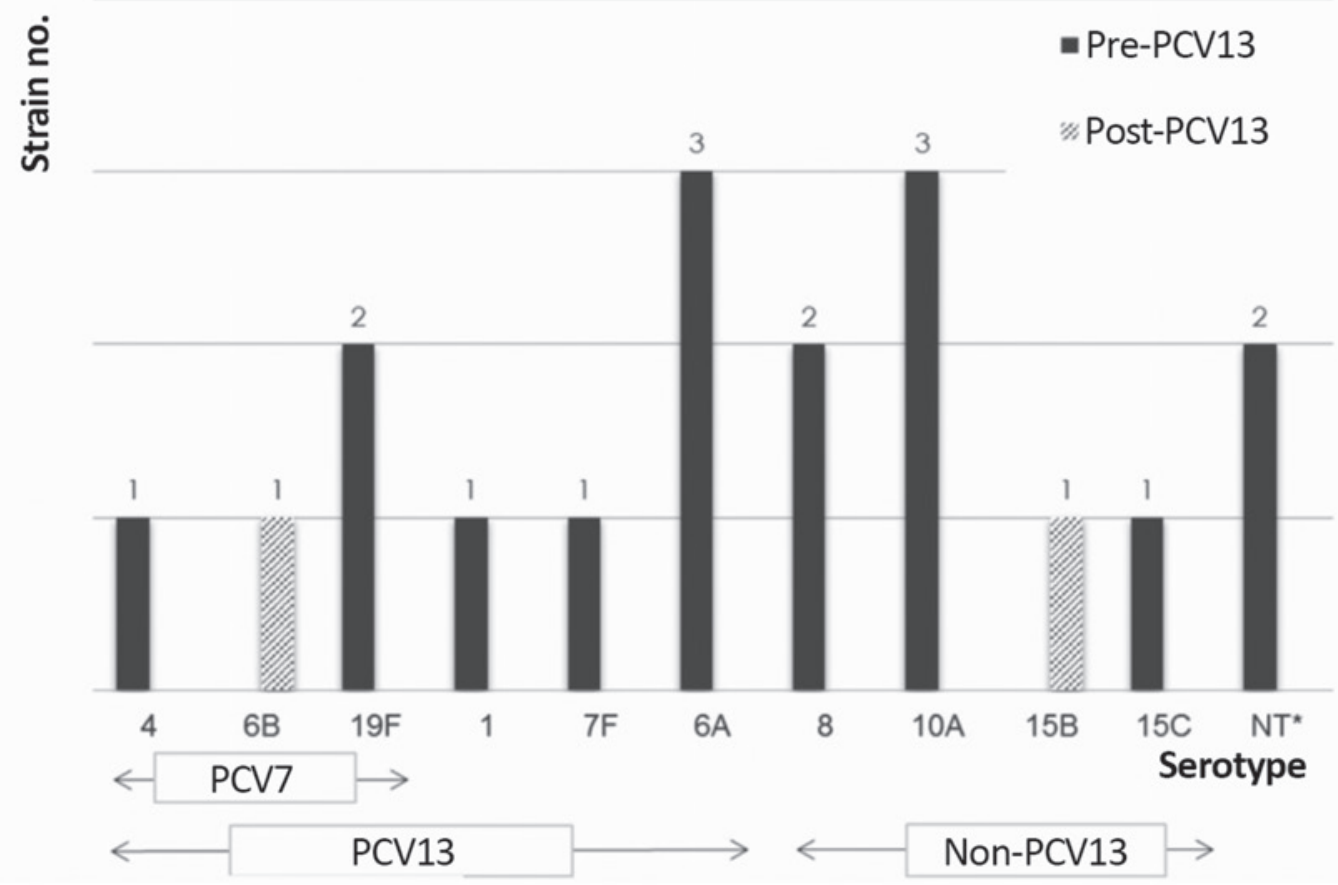

* NT: nontypeable strains.

PCV7: 7-valent pneumococcal conjugate vaccine; PCV13: 13-valent pneumococcal conjugate vaccine. 
Data on serotype replacement for the PCV13 obtained to date are not conclusive. Recent population studies conducted in places that have introduced the PCV13 into the pediatric immunization schedule have demonstrated a decline in IPD incidence for all serotypes and across all age groups. ${ }^{10}$

In our series, we only detected 2 cases in the post-PCV13 period, which may be related to the immunization "herd effect" even if this immunization has not been established systematically. Such indirect effect has also been observed in Navarra, where IPD incidence had significantly reduced in individuals aged 5 to 64 and $\geq 65$ years old between 2010 and 2013. ${ }^{11}$

Mortality was lower compared to other studies that showed an $8 \%$ mortality rate in the USA and Europe. ${ }^{12}$ The only fatal case in our series had developed leukopenia, which is associated with a higher mortality. ${ }^{13}$ The rate and type of longterm sequelae are consistent with those observed in other series that found neurological sequelae in $20-40 \%$ of PM patients. ${ }^{12}$

The main sequela was hearing impairment, as described by Mencía Bartolomé et al. ${ }^{14}$ Given the small sample size, the higher number of sequelae observed in the cases caused by the serotypes included in the PCV13 should not be considered significant. No publications describing a higher incidence of sequelae associated with a certain causative serotype have been found.

The results of our study should be interpreted in the context of its limitations. Although the study included all PM cases seen at the referral hospital of Cantabria, a tertiary care facility, the sample size was small.

Therefore, data regarding serotype distribution should be deemed preliminary, and a longer study period is required. The recent introduction of the PCV13 into the immunization schedule gives rise to a new era in IPD prevention. It will be necessary to assess the long-term impact of the PCV13, in both the adult and the pediatric populations, because an overall reduction in PM incidence is expected. ${ }^{10}$

As a final conclusion, in spite of the advances made in PM prevention through immunization, it is still a serious pediatric health problem. Early symptom recognition, an improvement in the initial treatment provided at the emergency department, and an immediate transfer of patients to a facility with a pediatric ICU are key strategies to reduce morbidity and mortality.

\section{Acknowledgments}

We would like to thank the Department of Public Health and the Health Board of Cantabria for providing the data on immunization coverage and the pneumococcal vaccine status in our community.

\section{REFERENCES}

1. Casado Flores J, Fenoll A, Aristegui Fernández J, Rodrigo De Liria C, et al. Meningitis neumocócica en niños españoles: incidencia, serotipos y resistencia antibiótica. Estudio prospectivo multicéntrico. An Esp Pediatr 2002;57(4):295300 .

2. Asociación Española de Pediatría. Neumococo. En Manual de vacunas en línea de la Asociación Española de Pediatría. Capítulo 31: Actualización Febrero 2016. [Accessed on: May 23 ${ }^{\text {rd }}$, 2016]. Available at: http://vacunasaep.org/ documentos/manual/cap-31.

3. Fenoll A, GranizoJJ, Aguilar L, Giménez MJ, et al. Temporal trends of invasive Streptococcus pneumoniae serotypes and antimicrobial resistance patterns in Spain from 1979 to 2007. J clin Microbiol 2009;47(4):1012-20.

4. Ciancotti Oliver LR, Huertas Zarco I, Pérez Pérez E, Carmona MartíE, et al. Enfermedad neumocócica invasiva en la Comunitat Valenciana. Seis años de vigilancia (20072012). Enferm Infecc Microbiol clin 2015;33(3):149-55.

5. Instituto Nacional de Estadística. Datos del censo de Cantabria. Población residente por fecha, sexo y edad. [Accessed on: May 23 $\left.{ }^{\text {rd }}, 2016\right]$. Available at: http://www. ine.es/jaxiT3/Tabla.htm?t=9681\&L=0.

6. González A, Viloria LJ, Sanz JA, Ansorena L. Incidencia de enfermedad neumocócica invasiva en Cantabria (19952001) e implicaciones para el calendario vacunal. Gac Sanit 2003;17(6):453-7.

7. EUCAST. Breakpoint tables for interpretation MICs and zone diameters, Versión 6.0. [Accessed on: May 23 ${ }^{\text {rd }}, 2016$ ]. Available at: http://www.eucast.org/fileadmin/src/ media/PDFs /EUCAST_files/Breakpoint_tables/v_6.0_ Breakpoint_table.pdf.

8. Grupo de trabajo de la Ponencia de Registro y Programa de Vacunas. Enfermedad invasora por Streptococcus pneumoniae. Implicaciones dela vacunación con la vacuna conjugada heptavalente. España: Ministerio de Sanidad y Consumo, Abril 2006. [Accessed on: May 23 ${ }^{\text {rd }}, 2016$ ]. Available at: https:/ / www.murciasalud.es/recursos / ficheros/84893-neumococo_mayo2006.pdf.

9. Grupo de Trabajo de Neumococo 2009. Nuevas vacunas antineumocócicas conjugadas. Ministerio de Sanidad y Política Social.España:MinisteriodeSanidad y PolíticaSocial, 2010. [Accessed on:May23 ${ }^{\text {rd }}$,2016]. Availableat: http:/ / www. msssi.gob.es/profesionales/saludPublica / prevPromocion/ vacunaciones/docs/Vacunas_Antineumococicas_ conjugadas2010.pdf.

10. Grupo de Trabajo Vacunación frente a neumococo en GR 2015, de la Ponencia de Programas y Registro de Vacunaciones. Vacunación frente a neumococo en grupos de riesgo. Madrid: Ministerio deSanidad, Servicios Sociales e Igualdad, mayo 2015. [Accessed on: May 23 ${ }^{\text {rd }}, 2016$ ]. Available at: http://www.msssi.gob.es/profesionales / saludPublica/prevPromocion/vacunaciones / docs / Neumococo_Gruposriesgo.pdf.

11. Guevara M, Ezpeleta C, Gil-Setas A, Tarroba L, et al. Reduced incidence of invasive pneumococcal disease after introduction of the 13-valent conjugate vaccine in Navarre, Spain, 2001-2013. Vaccine 2014;32(22):2553-62.

12. Stockmann C, Ampofo K, Byington CL, Filloux F, et al. Pneumococcal Meningitis in Children: Epidemiology, Serotypes, and Outcomes From 1997-2010 in Utah. Pediatrics 2013;132(3):421-8.

13. Östergaard C, Konradsen HB, Samuelsson S. Clinical presentation and prognostic factors of Streptococcus pneumoniae meningitis according to the focus of infection. BMc Infect Dis 2005;5:93.

14. Mencía Bartolomé S, Casado Flores J, Marín Barba C, González-Vicent M, et al. Meningitis neumocócica en la infancia. Revisión de 28 casos. An Pediatr 2000;53(2):9. 